\title{
Effect of contamination and adulteration of wax foundations on the brood development of honeybees
}

\author{
Abdulrahim T. Alkassab ${ }^{1}$, David ThorbahN ${ }^{1}$, Malte Frommberger ${ }^{1}$, \\ Gabriela BischofF ${ }^{2}$, Jens Pistorius ${ }^{1}$ \\ ${ }^{1}$ Institute for Bee Protection, Julius Kühn-Institute (JKI) - Federal Research Centre for Cultivated Plants, Messeweg 11/ \\ 12, Braunschweig, Germany \\ ${ }^{2}$ Institute for Bee Protection, Julius Kühn-Institute (JKI) - Federal Research Centre for Cultivated Plants, Königin-Luise- \\ Str. 19, Berlin, Germany
}

Received 13 September 2019 - Revised 7 January 2020 - Accepted 6 February 2020

\begin{abstract}
Various reports recently informed about the effects of contaminated or adulterated wax foundations as a main cause of poor brood and colony development. Beekeepers reported that affected colonies were showing a holey brood pattern and a decline in population size. Twenty-five samples of wax foundations were collected from different sources in Germany. Samples were analyzed using a multi-residue analysis for 147 insecticides, acaricides, and varroacides to investigate the actual load of contamination in beeswax. Furthermore, the effect of selected contaminated and/or adulterated wax foundations on colony and brood development of honeybees was evaluated under field conditions. Our results show that 38 active substances in total were found in the wax samples. Acaricides used in-hive were the most frequently detected contaminants at high concentrations. Trace concentrations of plant protection products and biocides were also found. In the field trials, a significant influence of stearin-adulterated wax on population size, the number of capped brood cells, and termination rate was found compared with the reference. No detectable effects of other treatments on the investigated parameters were observed.
\end{abstract}

\section{Honeybee / Wax foundation / Stearin / Residue / Acaricides}

\section{INTRODUCTION}

The use of beehives with removable frames and wax foundations is a common practice in commercial beekeeping, allowing better inspection of hive problems, such as varroa mite and American foulbrood, and easier honey harvest. In good beekeeping practice, regular comb replacement plays a critical role in the hygienic conditions of the bee

Electronic supplementary material The online version of this article (https://doi.org/10.1007/s13592-020-00749-2) contains supplementary material, which is available to authorized users.

Corresponding author: Abdulrahim T. Alkassab abdulrahim.alkassab@julius-kuehn.de Manuscript editor: Monique Gauthier colony (Fries 1988; Piccirillo and De Jong 2004). Due to the important role of the combs for rearing the bee brood and food storage, the construction of combs in honeybee colonies is considered one of the essential functions of the bees, determining the development of the colonies.

Recently, an increasing number of reports dealt with the effects of contaminated or adulterated foundations as a main cause of poor brood and colony development. Beekeepers reported that affected colonies were showing a holey brood pattern and a decline in population size. The bees accepted the comb material in the breeding area poorly, and young larvae died. The symptoms have been linked to various possible causes including diseases, poorquality queens, residues of pesticides in wax, and a poor quality of the wax foundation. 
Contamination of the wax foundation with various contaminants used in apiculture and agriculture has been reported. Some of these residues are relatively persistent in wax and could, therefore, accumulate over time due to their fat-soluble properties and the low replacement rate of wax over several years (Chauzat and Faucon 2007; Mullin et al. 2010; Lambert et al. 2013). Many surveys in Europe and the USA have shown widespread use of acaricides, resulting in a high level of contamination in beeswax. The most frequently detected pesticide residues in beeswax samples were coumaphos and fluvalinate (Chauzat and Faucon 2007; Lodesani et al. 2008; Ravoet et al. 2015; Calatayud-Vernich et al. 2017). Calatayud-Vernich et al. (2017) reported the maximum concentrations of coumaphos, fluvalinate, and amitraz in Spanish beeswax to be $26.86,3.59$, and $6.88 \mathrm{mg} / \mathrm{kg}$, respectively. Among insecticides, the organophosphate chlorpyrifos was also frequently detected in beeswax samples (Mullin et al. 2010; Calatayud-Vernich et al. 2017). Wallner (1999) reported that coumaphos could be found at a high percentage $(62.5 \%)$ in wax foundations produced in Germany at concentrations of $0.5-3.5 \mathrm{mg} / \mathrm{kg}$.

The impacts of such acaricides on different bee castes at different levels have been investigated by various studies, presenting adverse effects like reduction of spermatozoa production in drone honeybees (Burley et al. 2008; Tihelka 2018) and lower acceptance rates in queen brood cells (Haarmann et al. 2002).

Most recently, plastic foundations coated with pesticide-free beeswax have been treated with field-relevant doses of amitraz, tau-fluvalinate, and coumaphos or a combination of chlorothalonil and chlorpyrifos. None of these studies found any adverse effects on colony growth (Payne et al. 2019).

On the other hand, the quality of the commercial wax foundation has been reported to play an essential role in the acceptance by bees and in brood rearing (Wallner 2005). According to EURegulation No. 231/2012, the quality of the use of beeswax as a food additive was defined (Commission Regulation (EU) 2012). Furthermore, in Belgium, there are action limits in use to protect bee health in related to pesticide residues and adulteration (FASFC; Advice Scientific Committee 2018). However, adulterations of wax foundations with cheaper vegetal or industrial waxes including paraffin or stearin have been increasing as of late. Some researchers investigated the impacts of adulteration on colony development of honeybee. Semkiw and Skubida (2013) investigated the effect of adulterated beeswax foundations with paraffin up to $50 \%$ and did not find any negative effects on brood and colony development.

On the other hand, the effect of stearin adulteration was reported by Reybroeck (2017), where clear brood losses at stearin concentration between 15 and $40 \%$ were observed. In further experiment by Reybroeck (2018), the adulterated beeswax foundations with stearin up to $7.5 \%$ showed adverse effects on brood development. However, detailed information of the effect of wax foundations with different quality on the bee behavior, symptoms, and colony development is needed to clarify the possible causes of reported observations by beekeepers regarding the poor brood and colony development.

In the current study, our aims were (1) to determine the current status of the contamination level in beeswax in Germany and (2) to compare the effects of stearin adulteration with the effects of pesticide residues and provide detailed information about the symptoms and colony development.

\section{MATERIALS AND METHODS}

\subsection{Sample collection and residual analysis of wax foundation}

Twenty-five samples of wax foundations were collected from different sources including beekeepers and commercial suppliers to be analyzed using a multi-residue analysis. In the evaluation of the measurement data, the focus was set on 147 insecticides, acaricides, and varroacides.

\subsection{Identification and quantification of the residues in wax samples}

The samples (approx. $5 \mathrm{~g}$ ) were weighed in glass centrifuge tubes and a surrogate standard 
solution (acetamiprid-d3, pirimicarb-d6, and chlorpyrifos-d10), and $30 \mathrm{~mL}$ of an acetone/ water mixture $(2: 1 \mathrm{v} / \mathrm{v})$ was added. The tubes were closed and left to stand for $30 \mathrm{~min}$. Subsequently, the samples were homogenized with a disperser (MICCRA) and then centrifuged for $10 \mathrm{~min}$ at $3000 \mathrm{rpm}$. After centrifugation, $15 \mathrm{~mL}$ of the supernatant sample extract was removed and, after adding $5 \mathrm{~mL}$ of a sodium chloride solution $(20 \%)$, transferred onto a Chem Elut ${ }^{\circledR}$ cartridge. After waiting for $15 \mathrm{~min}$, the samples were eluted with dichloromethane $(2 \times 50 \mathrm{~mL})$. The eluates were evaporated to dryness and the remaining extract dissolved with acetonitrile $(2 \mathrm{~mL})$ containing the predominantly isotopelabeled internal standards using an ultrasonic device (10 s) and stored in a freezer. The next day, the cold samples were filtered (syringe filter: PTFE $0.2 \mu \mathrm{m}$ ).

Identification and quantification of the target substances in the sample extracts were carried out by means of LC-MS/MS and GC-MS methods. The LC-MS/MS system used was a Prominence UFLC XR HPLC (SHIMADZU) coupled to a triple quadrupole mass spectrometer 4000 QTRAP (SCIEX) equipped with an electrospray ionization (ESI) source. The employed GC-MS system was a DSQ II (single-stage quadrupole mass spectrometer) with TRACE GC Ultra (Thermo Fisher Scientific) and CTC CombiPal autosampler (CTC Analytics). The substances were identified by their retention time, three MRM transitions (LC-MS/MS), and full-scan spectra (GC-MS), respectively. The quantification was carried out according to the internal standard method using matrix-matched calibration standards.

\subsection{Study design and colony establishment}

Three different variants from the previously analyzed wax foundation were selected. The following treatment groups were used: (T1) commercial beeswax with relatively high residues of varroacides $(2780 \mu \mathrm{g} / \mathrm{kg}$ fluvalinate, $169 \mu \mathrm{g} / \mathrm{kg}$ coumaphos, and $2900 \mu \mathrm{g} / \mathrm{kg}$ thymol), (T2) commercial beeswax with about $20 \%$ stearin content and $442 \mu \mathrm{g} / \mathrm{kg}$ fluvalinate, and (T3) reference wax foundation mixed with a high concentration of varroacides $(10,000 \mu \mathrm{g} / \mathrm{kg}$ fluvalinate, $10,000 \mu \mathrm{g} / \mathrm{kg}$ coumaphos, and 10,000 $\mu \mathrm{g} / \mathrm{kg}$ thy$\mathrm{mol})$. These variants were tested due to the high detected residues of the most frequently detected overall samples and due to the reported synergistic effect between them (Johnson et al. 2009, 2013); (C) reference wax foundation, a nearly residuefree wax foundation, where only traces of thiacloprid $(0.3 \mu \mathrm{g} / \mathrm{kg})$ and primicarb $(1.4 \mu \mathrm{g} / \mathrm{kg})$ were detected. The wax of groups T1 and T2 contained additional traces of several pesticides and biocides (Table S1).

In the first experiment, the wax foundations from the wax of the 4 groups were cut into strips of $9.5 \times 19.5 \mathrm{~cm}$. One strip from each experimental group was placed side by side in frames, then hung in the brood nest of six strong colonies to give the bees the opportunity to choose their preferred wax. To avoid positional effects on the frames, the wax strips were fixed in different positions. After that, one frame was hung at the same position in the center of the nest of honeybee colonies with approx. 12,000 bees and sister queens. The comb construction was observed and photographed at regular intervals over a full breeding cycle (Figure 3a).

In the second experiment, 20 colonies ( 5 per group) were built from artificial swarms $(500 \mathrm{~g}$ bees, sister queens). Each colony received four foundations from one of the experimental groups. All colonies were fed with $4 \mathrm{~L}$ sugar solution (Apiinvert) and $400 \mathrm{~g}$ pollen pastry (Neopoll). Five days after building the experimental colony, one of the combs, which had initially contained eggs, was photographed weekly over 7 weeks to evaluate the exact brood development and termination rate. On each photographed comb, 200-400 cells were marked, and their development over 7 weeks was evaluated using the HiveAnalyzer software with indicated brood indexes according to Schur et al. (2003) (Figure 3b). In addition, colony development was estimated using the Liebefeld method over two breeding cycles.

\subsection{Statistical analysis}

The differences between treatments were analyzed using generalized linear mixed models (GLMM) with "treatment and assessment date" 
as fixed factors and "colony" as a random factor. Analysis of variance (ANOVA) was performed to detect the differences in the termination rate between treatments.

All data analyses were conducted with the software SPSS v. 24 (SPSS Inc., Chicago, IL, USA) at the significance level of 0.05 .

\section{RESULTS}

\subsection{Residual concentrations in wax foundations}

In total, 38 active substances were found in the wax samples. More than $50 \%$ of the samples contained 16-20 contaminants. Among them, acaricides were the most frequently detected contaminants (Figure 1).

Relatively high levels of acaricides were identified, the maximum concentrations amounting to 9400,8470 , and $2589 \mu \mathrm{g} / \mathrm{kg}$ for thymol, taufluvalinate, and coumaphos, respectively. On the other hand, trace concentrations of plant protection products and biocides were also found. Chlorpyrifos was most commonly detected at a maximum concentration of $18 \mu \mathrm{g} / \mathrm{kg}$ (Figure 2).

\subsection{Preference experiment}

A delay in the building-up of stearinadulterated wax was visually observed during the first check on the next day after inserting the test frames. The bees had built up more than $90 \%$ of the area of the other three wax strips compared with lower than $10 \%$ of the area of the stearinadulterated wax strips. Thereafter, no differences could be observed in the building-up of wax strips during the next assessments.

In the stearin-adulterated wax strips (T2), eggs and already-developed larvae were often removed by the bees. The larvae could develop in the cells until capping after several instances of removal and cleaning (Figure 3a). As a result, the developing brood was remarkably full of gaps and was inconsistent (Figure 3b). In the comb strips of other treatments, the brood developed normally.

\subsection{Effect of contamination and adulteration of wax foundations on brood and colony development}

The same symptoms as in the preference experiment were observed concerning the brood

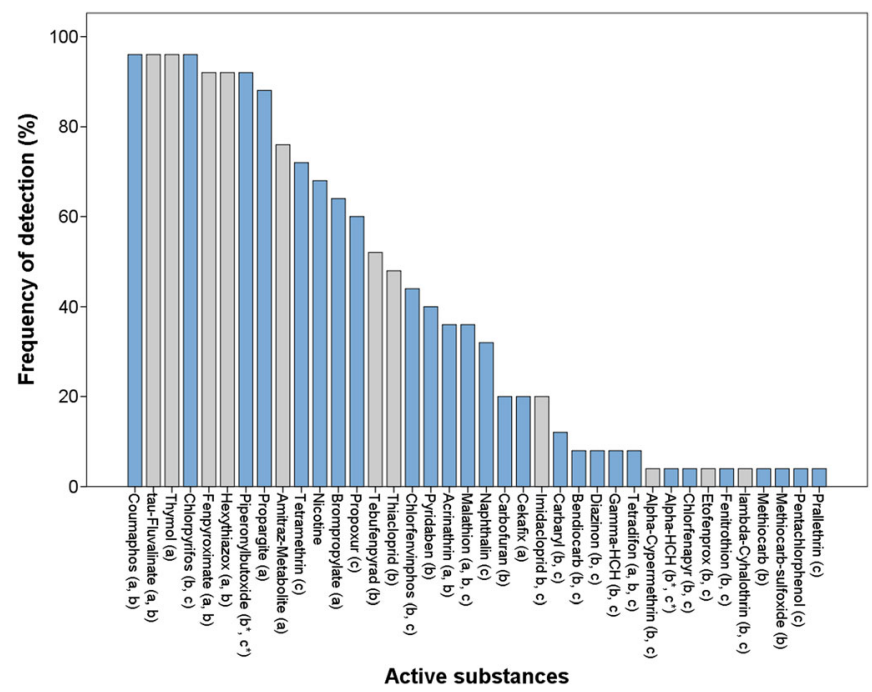

Figure 1. Frequency distribution of the detected active substance in the samples $(n=25)$. Blue bars show the active substances which are not authorized in Germany for use in agriculture and/or beekeeping. The small letters behind each active substance indicate the classification of usage. (a) indicates the veterinary products, (b) indicates plant protection product, and (c) indicates the biocides. 


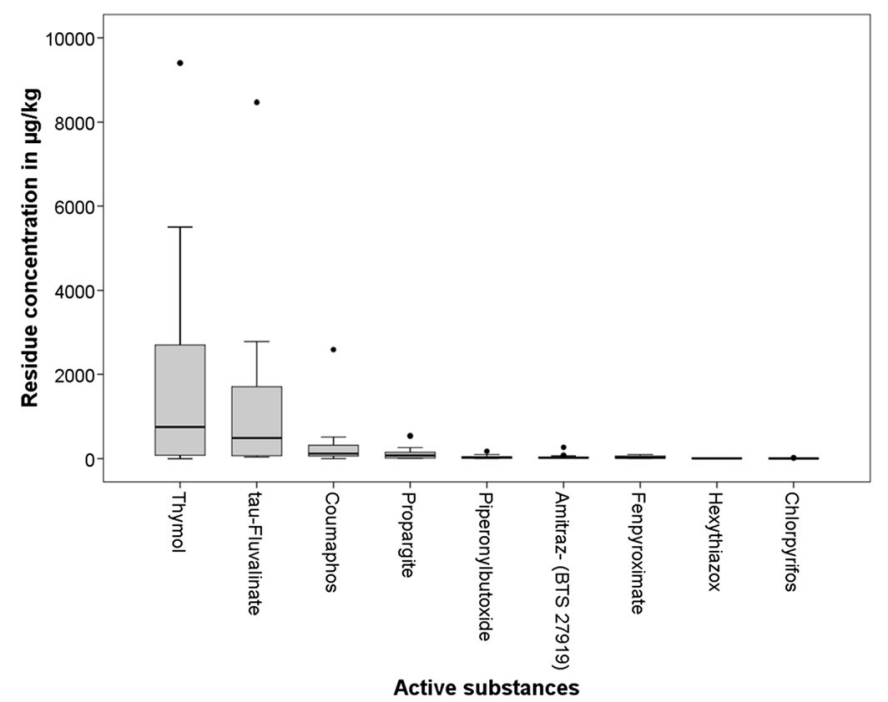

Figure 2. Residue concentrations of the most commonly found pesticides in analyzed wax foundations $(n=25)$. The concentrations are shown as boxplots with the median; the edges of the box indicate the $25^{\text {th }}$ and $75^{\text {th }}$ percentiles. Outliers are shown as circles.

development (Figure 4). Basically, the colony strength after the first brood cycle was significantly lower in T2 (GLMM, $p<0.05)$ compared with that of other variants and reference. After the second brood cycle, the colony strength in $\mathrm{T} 2$ decreased again, while in the other variants and the reference, a significant increase in the colony strength was observed (Figure 5a). In addition, the estimated average amount of capped brood cells per colony was approximately $55 \%$ lower in variant T2 compared with that of the reference (Figure 5b). Also in comparison with the reference, the termination rate of brood cells before capping was significantly higher in the variant $\mathrm{T} 2$ (ANOVA, $p<0.05$ ). Brood development in T2 resulted in atypical brood cycles (Figure 6a, b).

No detectable effects of other treatments on the colony strength and the number of capped brood cells were observed.

\section{DISCUSSION}

Our results demonstrate that the analyzed wax foundations are frequently contaminated with several active substances. The detected substances could be categorized as substances used outside of the colony (plant protection products), directly applied to the colony (veterinary products), or biocides
(Figure 1). Mainly, the residues with high frequencies and concentrations originate from apicultural applications against varroa mite like coumaphos, fluvalinate, and thymol. It was reported that most acaricides are fat-soluble, non-volatile and, in general, do not degrade in beeswax (Büchler and Maul 1991; Wallner 1999). Thus, residues of these molecules may accumulate in beeswax over many years of treatment. Accordingly, some of the detected acaricides are at present neither authorized in Germany nor in the European Union, e.g., propargite. Their presence can be explained by historical contamination and the recycling of old combs or the illegal use of such substances. Previous studies have reported the occurrence of such substances in beeswax (Chauzat and Faucon 2007; Nguyen et al. 2009; Mullin et al. 2010). Furthermore, trace concentrations of plant protection products and biocides were also identified. Chlorpyrifos, a highly toxic substance $\left(\mathrm{LD}_{50}\right.$ contact $59 \mathrm{ng} /$ bee and oral 250 ng/bee, Pesticide Properties Data Base (PPDB n.d.)), was detected in our study at high frequencies and a maximum concentration of $18 \mu \mathrm{g} / \mathrm{kg}$. These results indicate a high persistence of chlorpyrifos in beeswax during wax recycling. On the other hand, a higher concentration of $978 \mu \mathrm{g} / \mathrm{kg}$ is detected in Spanish and American beeswax (CalatayudVernich et al. 2017), which could indicate the 


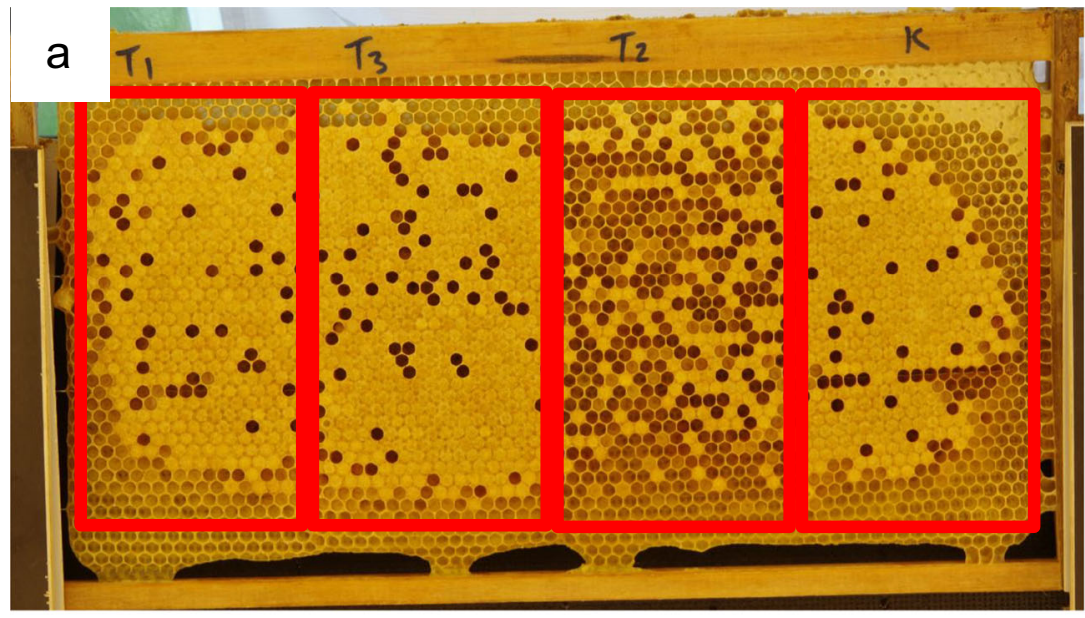

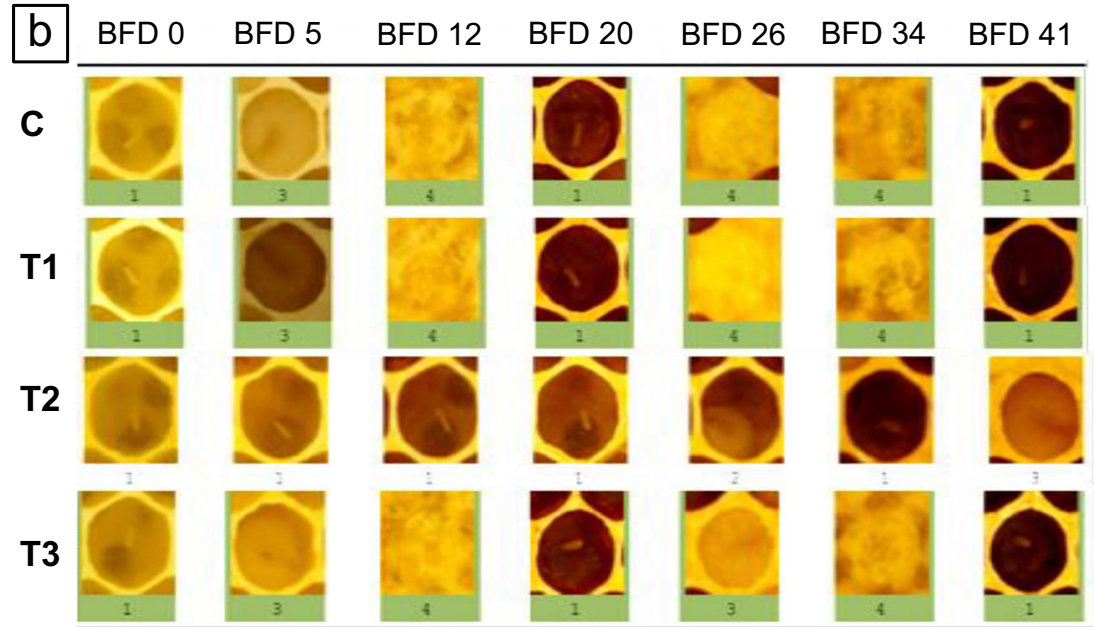

Figure 3. a Comparison of the capping rate of brood cells in the tested wax foundations in the same colony. b Example of the development process in the same cell of different wax foundations over two brood cycles. Several instances of removal and cleaning are required in the stearin-adulterated wax until capping is achieved. The abbreviation BFD indicates the brood fixing day; the number (1 to 4) under the each cell indicates the brood indexes. (C) reference wax foundation, (T1) commercial beeswax with relatively high residues of varroacides, (T2) commercial beeswax with about $20 \%$ stearin content and $442 \mu \mathrm{g} / \mathrm{kg}$ fluvalinate, and (T3) reference wax foundation mixed with a high concentration of varroacides $(10,000 \mu \mathrm{g} / \mathrm{kg}$ of each fluvalinate, coumaphos, and thymol).

widespread use of this insecticide in the areas of honeybee colonies where beeswax came from rather than its persistence in beeswax during wax recycling.

In the current study, we aim to determine the effects of contaminated as well as adulterated wax foundations on the development of newly established colonies. Our results showed no detectable impacts of contaminated beeswax by the tested and field-relevant concentrations on the colony strength and number of capped brood cells. These results are in agreement with the results reported by Payne et al. (2019). They did not find any adverse effects of treated plastic foundations with fieldrelevant doses of amitraz, tau-fluvalinate, and coumaphos or chlorothalonil and chlorpyrifos on colony development. Other studies showed that a high level of contamination in beeswax affected brood development (Wu et al. 2011) and reduced the postemergence performance of adult workers and queens 

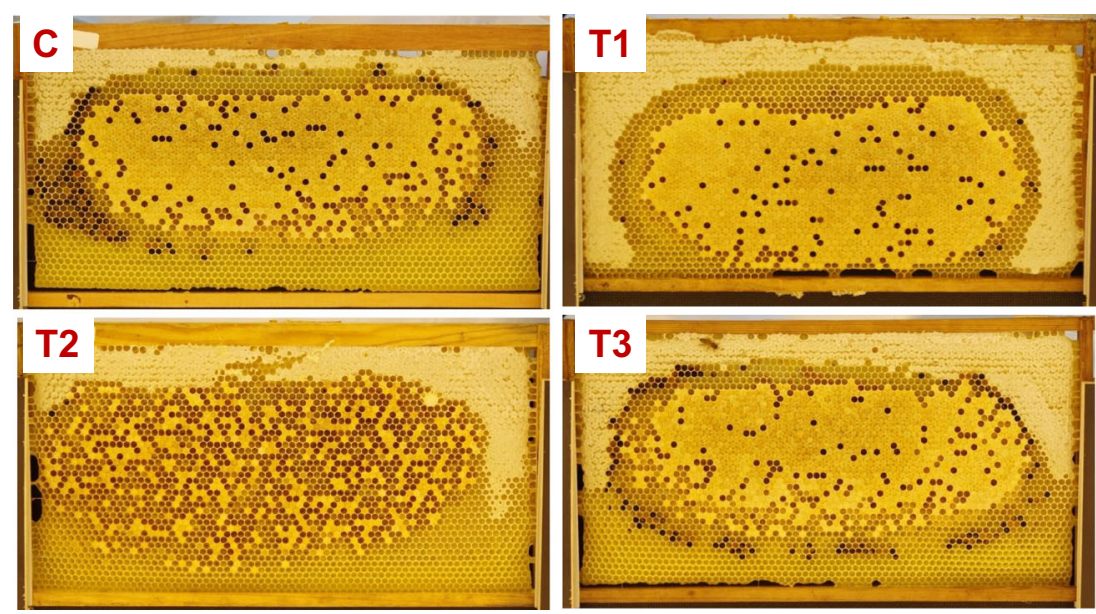

Figure 4. Brood development on the same day in the tested wax foundations in different colonies. Inconsistent development of brood cells with many gaps is shown in the stearin-adulterated wax. (C) reference wax foundations, (T1) commercial beeswax with relatively high residues of varroacides, (T2) commercial beeswax with about $20 \%$ stearin content and $442 \mu \mathrm{g} / \mathrm{kg}$ fluvalinate, and (T3) reference wax foundation mixed with a high concentration of varroacides $(10,000 \mu \mathrm{g} / \mathrm{kg}$ of each fluvalinate, coumaphos, and thymol).

(Wu et al. 2012; Pettis et al. 2004; Collins and Pettis 2013). Moreover, synergistic effects of coumaphos and fluvalinate on adult bees at relatively high concentrations were reported (Johnson et al. 2009 and 2013). In this context, the exposure of adult bees as

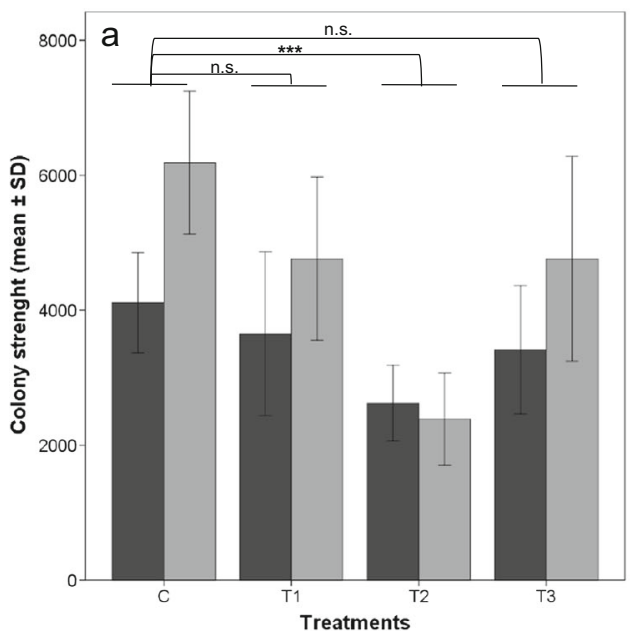

well as immature stages to the contaminants through the transfer from beeswax to other matrices such as honey, bee bread, royal jelly, and worker jelly should also be investigated as an important exposure way. Reybroeck et al. (2010) demonstrated that

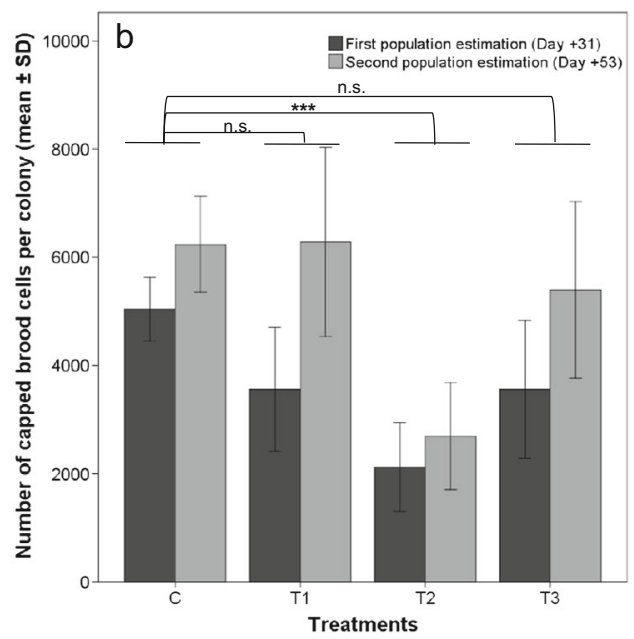

Figure 5. a Number of bees. b Number of capped brood cells of the tested colonies on day +31 and +53 after the start of the experiment $(n=5)$. Bars represent mean \pm SD. Asterisks indicate the significant differences at $p<0.05$. n.s. indicates nonsignificant differences. (C) reference wax foundation, (T1) commercial beeswax with relatively high residues of varroacides, (T2) commercial beeswax with about $20 \%$ stearin content and $442 \mu \mathrm{g} / \mathrm{kg}$ fluvalinate, and (T3) reference wax foundation mixed with a high concentration of varroacides $(10,000 \mu \mathrm{g} / \mathrm{kg}$ of each fluvalinate, coumaphos, and thymol). 

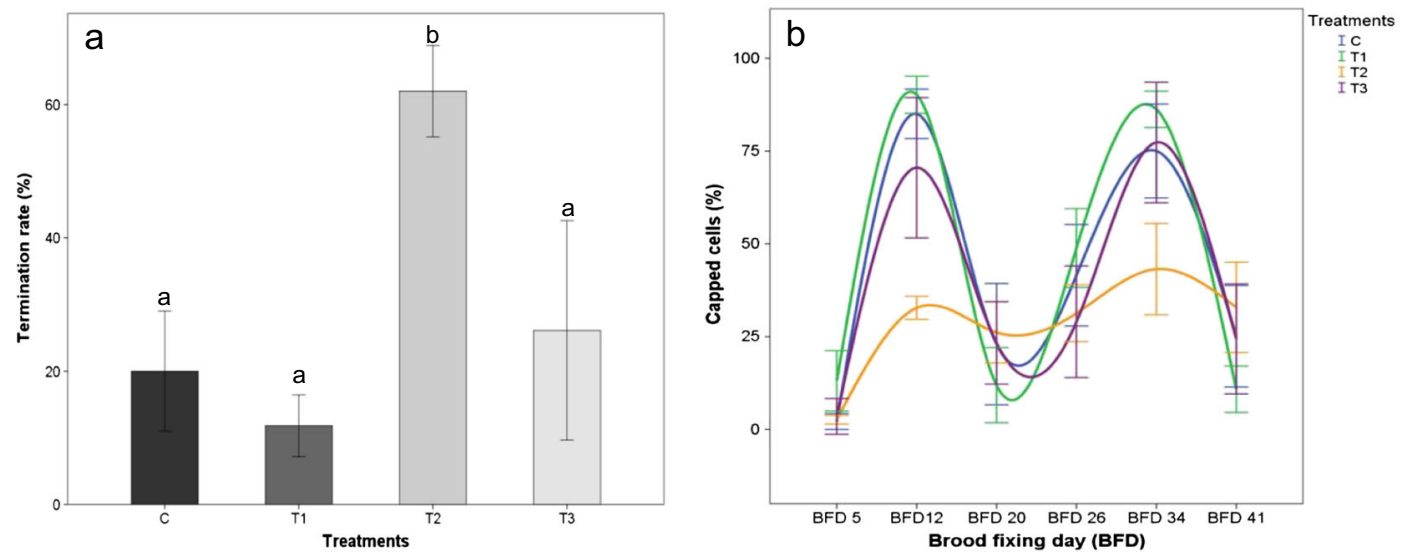

Figure 6. a Termination rate. b Capping rate of observed cells over two brood cycles ( $n=5, n=200-400$ cells/ colony). BFD indicates the brood fixing day. Bars sharing the same letter do not differ significantly at $p<0.05$. (C) reference wax foundation, (T1) commercial beeswax with relatively high residues of varroacides, (T2) commercial beeswax with about $20 \%$ stearin content and $442 \mu \mathrm{g} / \mathrm{kg}$ fluvalinate, and (T3) reference wax foundation mixed with a high concentration of varroacides $(10,000 \mu \mathrm{g} / \mathrm{kg}$ of each fluvalinate, coumaphos, and thymol).

sulfamethazine does not have strong lipophilic properties and quite easily migrates from the wax to the honey with a transfer ratio of up to $56.9 \%$. Aside from the data reported here, a further study is being conducted in our laboratory to investigate the transfer ratio of the most frequently detected contaminants from beeswax samples into other matrices including worker jelly, royal jelly, bee bread, and honey. The highest transfer ratio was found from wax to bee bread (Eckert et al. in preparation).

However, most studies conducted on the toxicological effects of detected active substances have been performed with individual bees using high concentrations and/or under artificial conditions (Wu et al. 2012; Dai et al. 2018).

On the other hand, tested adulterated wax foundations with stearin up to $20 \%$ in the present study showed adverse effects on brood development and colony strength. The termination rate of brood cells before capping was also significantly higher compared with that of the reference. Reybroeck (2017) and (2018) reported similar effects of adulterated beeswax foundations with stearin up to $7.5 \%$ on brood development. Otherwise, no adverse effects of adulterated beeswax foundation with paraffin up to $50 \%$ on brood and colony development were shown (Semkiw and Skubida 2013).

The bees seem to distinguish between the wax groups, where they reject the stearin-adulterated wax strips only on the first day, whereafter the bees built up the wax foundations of this variant. This delay in the building-up of adulterated wax could be related to the changed physicochemical parameters of the adulterated wax foundation including density, acid, saponification, ester, ratio number, iodine, peroxide, melting point, and ash content values. Bernal et al. (2005) reported that the most rejected foundation by bees showed higher or lower values. Furthermore, adulterated types of beeswax were reported to have high concentrations of even-chain hydrocarbons, free alcohols, and short-chain free acids (Jiménez et al. 2007), which could also affect the brood survivorship. In this study, dying-off of the young larvae occurred in the stearin-adulterated wax, where the young larvae were often removed multiple times by the bees before the larvae could develop in the cells until capping. An explanation for this behavior is the cleaning process to isolate the cell wall with a thin layer of propolis (Free and Williams 1974) and a fecal material (Jay 1963).

Overall, the results show a significant influence of stearin adulteration on the brood development of bee colonies. Residues of bee-toxic insecticides from plant protection products and biocides, which are detectable in trace amounts or low concentrations in almost all commercially available wax foundations, had no discernible effects 
on brood development. Further studies should be conducted to test whether there are underlying, reinforcing effects of adulterants with residues of contaminants.

\section{AUTHORS' CONTRIBUTION}

ATA designed experiments and analyzed data; DT and MF performed the experiments; GB performed the residue analysis; and JP read and corrected the manuscript. All authors read and approved the final manuscript.

\section{FUNDING INFORMATION}

Open Access funding provided by Projekt DEAL.

\section{COMPLIANCE WITH ETHICAL STANDARDS}

Conflict of interest The authors declare that they have no conflict of interest.

\section{OPEN ACCESS}

This article is licensed under a Creative Commons Attribution 4.0 International License, which permits use, sharing, adaptation, distribution and reproduction in any medium or format, as long as you give appropriate credit to the original author(s) and the source, provide a link to the Creative Commons licence, and indicate if changes were made. The images or other third party material in this article are included in the article's Creative Commons licence, unless indicated otherwise in a credit line to the material. If material is not included in the article's Creative Commons licence and your intended use is not permitted by statutory regulation or exceeds the permitted use, you will need to obtain permission directly from the copyright holder. To view a copy of this licence, visit http://creativecommons. org/licenses/by/4.0/.

Influence de la contamination et de la falsification des parois médianes sur le développement du couvain des abeilles
Einfluss der Kontamination und Verfälschung von Mittelwänden auf die Brutentwicklung von Honigbienen.

Honigbiene / Mittelwand / Stearin / Rückstände / Acarizide.

\section{REFERENCES}

Bernal J.L., Jiménez J.J., del Nozal M.J., Toribio L., Martín M.T. (2005) Physico-chemical parameters for the characterization of pure beeswax and detection of adulterations. Eur. J. Lipid Sci. Technol. 107 (3), 158-166

Büchler R., Maul V. (1991) The after-effect of Bayvarol treatment in honey bee colonies on varroamites introduced later on. Apidologie 22 (4), 389-396

Burley L.M., Fell R.D., Saacke R.G. (2008) Survival of honey bee (Hymenoptera: Apidae) spermatozoa incubated at room temperature from drones exposed to miticides. J. Econ. Entomol. 101 (4), 1081-1087

Calatayud-Vernich P., Calatayud F., Simó E., Picó Y. (2017) Occurrence of pesticide residues in Spanish beeswax. Sci. Total Environ. 605, 745-754

Chauzat M.P., Faucon J.P. (2007) Pesticide residues in beeswax samples collected from honey bee colonies (Apis mellifera L.) in France. Pest Management Science: formerly Pesticide Science 63 (11), 1100-1106

Collins A.M., Pettis J.S. (2013) Correlation of queen size and spermathecal contents and effects of miticide exposure during development. Apidologie 44 (3), 351356

Commission regulation (EU) No 231(2012). Laying down specifications for food additives listed in Annexes II and III to Regulation (EC) No 1333/2008 of the European Parliament and of the Council. Official Journal of the European Union. https://eur-lex.europa. eu/eli/reg/2012/231/oj. (accessed January 6, 2020)

Dai P., Jack C.J., Mortensen A.N., Bustamante T.A., Ellis J.D. (2018) Chronic toxicity of amitraz, coumaphos and fluvalinate to Apis mellifera L. larvae reared in vitro. Scientific reports 8(1), 5635

Federal Agency for the Safety of the Food Chain (FASFC), Advice Scientific Committee (2018). The FASFC regarding the risk to bee health of contaminated and adulterated beeswax (dossier SciCom 2016/27). http://www.afsca. be/scientificcommittee/opinions/2018/(accessed January 6, 2020)

Free J.B., Williams I.H. (1974) Factors determining food storage and brood rearing in honeybee (Apis mellifera L.) comb. Journal of Entomology Series A, General Entomology 49 (1), 47-63 
Fries I. (1988) Comb replacement and nosema disease (Nosema apis Z.) in honeybee colonies. Apidologie 19 (4), 343-354

Haarmann T., Spivak M., Weaver D., Weaver B., Glenn T. (2002) Effects of fluvalinate and coumaphos on queen honey bees (Hymenoptera: Apidae) in two commercial queen rearing operations. J. Econ. Entomol. 95 (1), 2835

Jay S.C. (1963) The development of honeybees in their cells. J. Apic. Res. 2 (2), 117-134

Jiménez J.J., Bernal J.L., del Nozal M.J., Toribio L., Bernal J. (2007) Detection of beeswax adulterations using concentration guide-values. Eur. J. Lipid Sci. Technol. 109 (7), 682-690

Johnson R.M., Pollock H.S., Berenbaum M.R. (2009) Synergistic interactions between in-hive miticides in Apis mellifera. J. Econ. Entomol. 102 (2), 474-479

Johnson R.M., Dahlgren L., Siegfried B.D., Ellis M.D. (2013) Acaricide, fungicide and drug interactions in honey bees (Apis mellifera). PLoS One 8(1), e54092

Lambert O., Piroux M., Puyo S., Thorin C., L'Hostis M., Wiest L. et al (2013) Widespread occurrence of chemical residues in beehive matrices from apiaries located in different landscapes of Western France. PLoS One $8(6)$, e 67007

Lodesani M., Costa C., Serra G., Colombo R., Sabatini A.G. (2008) Acaricide residues in beeswax after conversion to organic beekeeping methods. Apidologie 39 (3), 324-333

Mullin C.A., Frazier M., Frazier J.L., Ashcraft S., Simonds R., Pettis J.S. (2010) High levels of miticides and agrochemicals in north American apiaries: implications for honey bee health. PLoS One 5 (3), e9754

Nguyen B.K., Saegerman C., Pirard C., Mignon J., Widart J., Thirionet B. et al (2009) Does imidacloprid seedtreated maize have an impact on honey bee mortality? J. Econ. Entomol. 102 (2), 616-623

Payne A.N., Walsh E.M., Rangel J. (2019) Initial exposure of wax foundation to agrochemicals causes negligible effects on the growth and winter survival of incipient honey bee (Apis mellifera) colonies. Insects $\mathbf{1 0}$ (1), 19

Pesticide Properties Data Base (PPDB) (n.d.). Agriculture and Environment Research Unit (AERU) at the University of Hertfordshire. https://sitem.herts.ac. uk/aeru/ppdb/en/Reports/154.htm.

Pettis J.S., Collins A.M., Wilbanks R., Feldlaufer M.F. (2004) Effects of coumaphos on queen rearing in the honey bee, Apis mellifera. Apidologie 35 (6), 605-610

Piccirillo G.A., De Jong D. (2004) Old honey bee brood combs are more infested by the mite Varroa destructor than are new brood combs. Apidologie 35 (4), 359364
Ravoet J., Reybroeck W., de Graaf D.C. (2015) Pesticides for apicultural and/or agricultural application found in Belgian honey bee wax combs. Bull. Environ. Contam. Toxicol. 94 (5), 543-548

Reybroeck, W. 2017. Field trial: effect of the addition of a mixture of stearic and palmitic acid (called stearin) to beeswax on the development of the worker bee brood. Final report: ILVO, Melle, 1-14. [online] https://www.health.belgium.be/de/node/31713 (accessed January 6, 2020)

Reybroeck, W. 2018. Field trial: effect of the addition of stearic and palmitic acid to beeswax on the development of the worker bee brood, Final report: ILVO, Melle, 1-22. [online] https://www.health.belgium. be/sites/default/files/uploads/fields/fpshealth theme file/verslag_veldproef_ilvo_2018_eng.pdf (accessed January $6, \overline{2020)}$

Reybroeck W., Jacobs F.J., De Brabander H.F., Daeseleire E. (2010) Transfer of sulfamethazine from contaminated beeswax to honey. J. Agric. Food Chem. 58(12), 7258-7265

Schur A., Tornier I., Brasse D., Mühlen W., von der Ohe W., Wallner K., Wehling M. (2003) Honey bee brood ring-test in 2002: method for the assessment of sideeffects of plant protection products on the honey bee brood under semi-field conditions. Bulletin of Insectology 56 (1), 1-7

Semkiw P., Skubida P. (2013) Comb construction and brood development on beeswax foundation adulterated with paraffin. Journal of Apicultural Science 57(1), $75-83$

Tihelka E. (2018) Effect of synthetic and organic acaricides on honey bee health: a review. Slov. Vet. Res. 55 (2), 119-140

Wallner K. (1999) Varroacides and their residues in bee products. Apidologie 30 (2-3), 235-248

Wallner K. (2005). Foundation causing honeybee brood damage. In Proceedings of ICPBR 9. International Symposium York, United Kingdom, 12-14 October 2005, p. 30.

Wu J.Y., Anelli C.M., Sheppard W.S. (2011) Sub-lethal effects of pesticide residues in brood comb on worker honey bee (Apis mellifera) development and longevity. PLoS One 6 (2), e14720

Wu J.Y., Smart M.D., Anelli C.M., Sheppard W.S. (2012) Honey bees (Apis mellifera) reared in brood combs containing high levels of pesticide residues exhibit increased susceptibility to Nosema (Microsporidia) infection. J. Invertebr. Pathol. 109 (3), 326-329

Publisher's note Springer Nature remains neutral with regard to jurisdictional claims in published maps and institutional affiliations. 